\title{
The effect of temperature on growth and competition between Sphagnum species
}

\author{
Angela Breeuwer - Monique M. P. D. Heijmans • \\ Bjorn J. M. Robroek · Frank Berendse
}

Received: 4 January 2007/Accepted: 7 January 2008/Published online: 19 February 2008

(C) The Author(s) 2008

\begin{abstract}
Peat bogs play a large role in the global sequestration of $\mathrm{C}$, and are often dominated by different Sphagnum species. Therefore, it is crucial to understand how Sphagnum vegetation in peat bogs will respond to global warming. We performed a greenhouse experiment to study the effect of four temperature treatments $(11.2,14.7$, 18.0 and $21.4^{\circ} \mathrm{C}$ ) on the growth of four Sphagnum species: S. fuscum and S. balticum from a site in northern Sweden and $S$. magellanicum and $S$. cuspidatum from a site in southern Sweden. In addition, three combinations of these species were made to study the effect of temperature on competition. We found that all species increased their height increment and biomass production with an increase in temperature, while bulk densities were lower at higher temperatures. The hollow species $S$. cuspidatum was the least responsive species, whereas the hummock species S. fuscum increased biomass production 13-fold from the lowest to the highest temperature treatment in monocultures. Nutrient concentrations were higher at higher temperatures, especially $\mathrm{N}$ concentrations of S. fuscum and S. balticum increased compared to field values. Competition between $S$. cuspidatum and $S$. magellanicum was not influenced by temperature. The mixtures of $S$. balticum with $S$. fuscum and $S$. balticum with $S$. magellanicum showed that $S$. balticum was the stronger competitor, but it lost competitive advantage in the highest temperature
\end{abstract}

Communicated by Allan Green.

A. Breeuwer $(\bowtie) \cdot$ M. M. P. D. Heijmans .

B. J. M. Robroek · F. Berendse

Nature Conservation and Plant Ecology,

Department of Environmental Sciences,

Wageningen University, P.O. Box 47,

6700 AA Wageningen, The Netherlands

e-mail: a.breeuwer@gmail.com treatment. These findings suggest that species abundances will shift in response to global warming, particularly at northern sites where hollow species will lose competitive strength relative to hummock species and southern species.

Keywords Bog - Cover change - Global warming . Greenhouse $\cdot$ Species composition

\section{Introduction}

Peat bogs play a large role in the global sequestration of C. Although northern peatlands cover only $2 \%$ of the total land surface, they store about one-third of the world soil C in the form of peat (Gorham 1991). It is therefore important to know how ombrotrophic bog ecosystems, which form a large part of northern peatlands, will respond to predicted climate changes, especially since the rise in temperature is expected to be above the global average at high latitudes (Christensen et al. 2007) where the majority of peat bogs occur (Kivinen and Pakarinen 1980; Gunnarsson 2005).

Vegetation in ombrotrophic bogs is often dominated by different Sphagnum species. The Sphagnum species account for the bulk of the $\mathrm{C}$ sequestration in peat because of their recalcitrant litter (Coulson and Butterfield 1978; Clymo and Hayward 1982; Limpens et al. 2003). Therefore, it is crucial to understand how Sphagnum vegetation in bogs will respond to global warming in order to predict the role of bogs as $\mathrm{C}$ sinks in the future. Several studies have revealed differences in production (Lindholm and Vasander 1990; Gerdol 1995; Asada et al. 2003; Gunnarsson 2005) and in decomposition rate (Rochefort et al. 1990; Johnson and Damman 1993; Belyea 1996; Limpens and Berendse 2003) between different Sphagnum species. These differences between species are often related to 
differences in microhabitat preference (Gunnarsson 2005). Within a bog, different Sphagnum species occur at different heights above the water table and at different positions along $\mathrm{pH}$ and nutrient gradients (Andrus 1986; Sjörs and Gunnarsson 2002; Limpens et al. 2003). The most obvious division in microhabitat preference is between hollow species, which grow in pools and at shallow water levels, and hummock species, which grow at deeper water levels. Hummock species can also grow at higher water levels, but they are then usually outgrown by hollow species (Rydin 1986, 1993, 1997). However, the competitive ability of species may differ between years, seasons and locations, and as such, competitive replacement occurs very slowly, if at all. This results in a relatively stable competitive balance between species (Rydin 1997).

Several studies found a positive relation between Sphagnum productivity and temperature (Moore 1989; Sonesson et al. 2002; Gunnarsson 2005). The positive effect that increased temperature might have on $\mathrm{C}$ sequestration in bogs is, however, often diminished by the positive effect of temperature on decomposition rates (Hobbie 1996). Increased decomposition rates also lead to increased rates of nutrient release from the peat layer, enhancing production rates even further. A change in temperature influences not only the production and decomposition of individual Sphagnum species but also the competitive balance that exists between species. An important challenge facing ecologists is to predict how climate change will alter species distributions in ecosystems (Mooney 1991). Robroek et al. (2007b) already found different responses in biomass production among species when temperature was increased. It can be imagined that when a species with high production and/or a low decomposition rate increases its relative abundance in a bog, this will increase the $\mathrm{C}$ storage capacity of the system.

Not only are there different competing species within a bog, but there are also differences in dominant species between bogs when different climatic regions are compared. In this study, we used species from two different sites. At the site in northern Sweden, Sphagnum balticum and Sphagnum fuscum are the dominant species while at the site in southern Sweden these species also occur, but Sphagnum magellanicum and Sphagnum cuspidatum are the most abundant species. This corresponds with the general distribution of these species in Europe since both S. magellanicum and S. cuspidatum occur further south than S. fuscum and S. balticum (Daniels and Eddy 1985).

To examine the effect of temperature on the competition between species, we performed a greenhouse experiment in which we studied the effect of four temperature treatments on the growth of the four species: $S$. fuscum and $S$. balticum from a northern Swedish site and $S$. magellanicum and S. cuspidatum from a southern Swedish site. Three combinations of species were made to study the effects of temperature on interspecific competition. In our experiment we tried to answer the following questions:

1. What is the effect of increased temperature on the growth of different Sphagnum species? We expect all species to show an increase in both height increment and biomass production as a direct result of increased temperature and indirectly through increased nutrient availability.

2. What is the effect of temperature on competition between species? Since S. fuscum and S. magellanicum grow in drier and therefore also warmer microhabitats than $S$. balticum and $S$. cuspidatum respectively, we expect these species to be better adapted to higher temperatures. S. magellanicum grows at more southern sites than $S$. balticum, so we expect this species to be better adapted to higher temperatures. Consequently, we hypothesize that increased temperature will have a positive effect on competitive abilities of the hummock and southern species, leading to a relatively larger increase in height increment and biomass production with temperature than for hollow and northern species.

\section{Materials and methods}

\section{Plant material}

In August 2004, Sphagnum cores (diameter $16 \mathrm{~cm}$, height $18-22 \mathrm{~cm}$ ) were collected at two different sites in Sweden. From the northern site Lappmyran $\left(64^{\circ} 09^{\prime} \mathrm{N}, 19^{\circ} 35^{\prime} \mathrm{E}\right), 30$ Sphagnum fuscum (Schimp) H. Klinggr cores and 40 Sphagnum balticum (Russ.) C. Jens. cores were collected. This site is a string flark mire or mixed mire with ridges of hummocks and hollows where $S$. fuscum is dominant on the hummocks and $S$. balticum in the dryer parts of the hollows. When identifying the species from this site in the lab, we found specimens of both S. balticum and Sphagnum angustifolium (Russ.) C. Jens. These species are difficult to distinguish, which both Russow (Smith 1978) and Klinggraff (Daniels and Eddy 1985) recognized when they identified both species as varietas of Sphagnum recurvum. In our samples, we were unable to quantify the exact percentages of $S$. balticum and $S$. angustifolium. As result, whenever we mention $S$. balticum, we are referring to a mixture of $S$ balticum and $S$. angustifolium.

From the southern site Saxnäs Mosse $\left(56^{\circ} 51^{\prime} \mathrm{N}, 13^{\circ} 27^{\prime}\right.$ E), 40 Sphagnum magellanicum (Brid.) cores and 30 Sphagnum cuspidatum (Hoffm.) cores were collected. At this site $S$. magellanicum occurs on the lawns and low hummocks and $S$. cuspidatum in the hollows and pools. 
Cores were taken from monospecific stands of each Sphagnum species ( $>95 \%)$ with sparse vascular plant cover $(<5 \%)$. The cores were placed in plastic containers (diameter $16 \mathrm{~cm}$, height $22 \mathrm{~cm}$ ). Vascular plants were clipped flush with the Sphagnum, and other Sphagnum species were removed with tweezers. The containers were brought to Wageningen and stored outside for 8 weeks before the greenhouse was available. As a result, containers from both sites could acclimate to the same climate to some extent.

\section{Experimental design}

At the start of the experiment, the containers were brought into the greenhouse and randomly divided over the treatments and five replicate blocks, with seven species combinations (four monocultures and three mixtures) and four temperature treatments per block. All four species were kept in monoculture and the following three species combinations were made to study interspecific competition: two northern species S. fuscum with S. balticum, two southern species $S$. magellanicum with $S$. cuspidatum and a northern with a southern species $S$. balticum with $S$. magellanicum. To study competition between a northern and a southern species we chose the combination of S. balticum and $S$. magellanicum because they occur at similar water levels. To make the combinations, the cores were cut into four equal quarters and two quarters of both species were placed alternately in an empty container. In potting the species combinations, we made certain that the surface of the mixture was uniform. We did not cut monocultures in four quarters, but another experiment showed no difference in water content between cut and uncut monocultures (Robroek et al. 2007a).

The experiment was conducted in four adjacent climate controlled greenhouse compartments from November 2004 till April 2005 for a total of 154 days. Each compartment was assigned one of four temperature treatments. Treatments and containers were switched between compartments every 2 weeks to minimize any effect of the different compartments. The position of the blocks and the position of containers within the blocks were also switched every 2 weeks. The average day temperatures in the four temperature treatments were $11.2,14.7,18.0$ and $21.4^{\circ} \mathrm{C}$, respectively (Table 1). During the dark period of $8 \mathrm{~h}$, the day temperature was lowered by approximately 3-9.3, $11.6,15.5$ and $18.9^{\circ} \mathrm{C}$, resulting in mean temperatures of $10.6,13.7,17.2$ and $20.6^{\circ} \mathrm{C}$ in temperature treatments 1,2 , 3 and 4 , respectively. In the region of the northern site, the mean temperature in July is $14.7^{\circ} \mathrm{C}$ (Alexandersson et al. 1991) and in the southern site the mean temperature in July is $17.0^{\circ} \mathrm{C}$ (Malmer et al. 2003). A light period of $16 \mathrm{~h}$ was applied. If light intensity was low during this period, SONT AGRO 400 (Philips Powertone 400) lamps were used.

Relative humidity during the day was set at $75 \%$. In the greenhouse it was not possible to keep the relative humidity exactly the same with all temperatures. The rise in temperature between treatments corresponded with a decrease in relative humidity, which caused an additional increase in vapour pressure deficit (VPD) with temperature (Table 1). The difference in relative humidity only explained $33 \%$ of the increase in VPD with the highest temperature. If relative humidity would have been equal in all compartments, VPD would still have been twice as high at temperature 4 as at temperature 1. Our highest VPD of $0.7 \mathrm{kPa}$ with a temperature of $21.4^{\circ} \mathrm{C}$ is actually still quite low compared to field conditions. Although not many data on VPD are published for similar ecosystems, Hobbie and Chapin (1998) did find the following values for VPD in Toolik Lake, Alaska, in June and July: in open field sites, $0.02-1.71 \mathrm{kPa}$ with temperatures ranging from 5.9 to $22.5^{\circ} \mathrm{C}$; and under small plastic greenhouses, 0.08 $3.83 \mathrm{kPa}$ with temperatures ranging from 6.4 to $31.1^{\circ} \mathrm{C}$. Dorrepaal et al. (2003) measured a VPD of 1.54 under normal conditions and 1.41 in open-top chambers with an average temperature of $15^{\circ} \mathrm{C}$ in June and July in Abisko, Sweden.

The water level was set to $1 \mathrm{~cm}$ below capitula at the start of the experiment. All species were subjected to the same water level, so that temperature was the only changing environmental variable. This relatively high

Table 1 Day and night mean values of temperature $\left({ }^{\circ} \mathrm{C}\right)$, relative humidity $(\%)$ and vapour pressure deficit $(V P D)(\mathrm{kPa})$ of the four treatments, $\pm \mathrm{SE}, n=154$

\begin{tabular}{|c|c|c|c|c|c|c|}
\hline \multirow[t]{2}{*}{ Treatment } & \multicolumn{2}{|l|}{ Temperature } & \multicolumn{2}{|c|}{ Relative humidity } & \multicolumn{2}{|l|}{ VPD } \\
\hline & Day & Night & Day & Night & Day & Night \\
\hline $\mathrm{T} 1$ & $11.2 \pm 0.04$ & $93 \pm 0.05$ & $81.9 \pm 0.4$ & $86.8 \pm 0.4$ & $0.24 \pm 0.01$ & $0.16 \pm 0.01$ \\
\hline $\mathrm{T} 2$ & $14.7 \pm 0.03$ & $116 \pm 0.05$ & $76.9 \pm 0.3$ & $81.8 \pm 0.5$ & $0.39 \pm 0.01$ & $0.25 \pm 0.01$ \\
\hline $\mathrm{T} 3$ & $18.0 \pm 0.02$ & $155 \pm 0.03$ & $75.2 \pm 0.4$ & $76.1 \pm 0.4$ & $0.51 \pm 0.01$ & $0.42 \pm 0.01$ \\
\hline $\mathrm{T} 4$ & $21.4 \pm 0.03$ & $189 \pm 0.04$ & $72.7 \pm 0.4$ & $73.0 \pm 0.5$ & $0.70 \pm 0.01$ & $0.59 \pm 0.01$ \\
\hline
\end{tabular}


water level was used for all species because hollow species cannot grow at low water levels; while hummock species can survive the environmental conditions of hollows quite well; nonetheless, they are absent from these areas because of biotic factors (Rydin and McDonald 1985). Grosvernier et al. (1997) found that growth in height and dry weight is equal for $S$. fuscum grown at water levels of $1 \mathrm{~cm}$ and $40 \mathrm{~cm}$ below moss surface while, for $S$. magellanicum and especially for Sphagnum fallax, growth in height and dry weight is much greater with the high water level.

During the experiment an artificial rainwater solution, an 8,000-fold dilution of a sea water solution (Garrels and Christ 1965), was added twice a week to bring the water level back to $1 \mathrm{~cm}$ below capitula. The amount of water added was used as a measure of evaporation. The drop in the water table was highest in the highest temperature treatment, but water level never dropped more than $6 \mathrm{~cm}$ below moss surface between two water additions. In a number of containers, Sphagnum grew higher than $1 \mathrm{~cm}$ above the container. To keep the water level at $1 \mathrm{~cm}$ below the moss surface, a plastic ridge was glued onto the containers and the crack was filled with silicone kit. Water content was measured using a theta probe (Delta-T Devices, Cambridge, UK) before the final harvest of the experiment. This was done 3-4 days after watering the containers for the last time, so the water content would reflect possible differences between treatments.

\section{Measurements}

Height increment of the Sphagnum carpet was measured non-destructively every month using a variation of the cranked wire method (Clymo 1970). We used plastic rods that were inserted to a depth of approximately $8 \mathrm{~cm}$ and anchored by plastic broom bristles, this method kept the cranked wires firm at the same place so they did not move with Sphagnum growth. Two plastic rods were inserted in the monocultures and one plastic rod was inserted in each quarter of the mixtures. The rods had a diameter of $1.5 \mathrm{~mm}$ and did not seem to interfere with the growth of the surrounding Sphagna.

At the end of the experiment, columns with a diameter of $5 \mathrm{~cm}$ were cut around each cranked wire and cut off at $5 \mathrm{~cm}$ length. Each column was put in a plastic Ziplock bag and fresh weight was determined. All bags were stored at $1{ }^{\circ} \mathrm{C}$ till further measurements could be taken. Capitula were defined as the top $1 \mathrm{~cm}$ of each individual plant and stem as the $1-4 \mathrm{~cm}$ part. Capitula and stems were separated per column and oven dried at $70^{\circ} \mathrm{C}$ for at least $48 \mathrm{~h}$ and then weighed. The weight of the total sample was used to calculate bulk density and the biomass production per squared centimetre to account for changes in capitulum density. For nutrient analyses, samples of capitula were pooled per species for each container. Total N, P and K concentrations were determined by digesting $300 \mathrm{mg}$ of homogeneous, milled material with $\mathrm{H}_{2} \mathrm{SO}_{4}$, salicylic acid, $\mathrm{Se}$ and $\mathrm{H}_{2} \mathrm{O}_{2}$. All samples were analysed for total $\mathrm{N}$ and $\mathrm{P}$ spectrophotometrically using an auto-analyzer (Skalar). $\mathrm{K}$ concentrations were measured with an atomic absorption spectrophotometer (Varian AAS). To compare capitulum bulk density and nutrient concentrations with field values, we collected five samples $(d=5 \mathrm{~cm})$ from monocultures of the four Sphagnum species in the two Swedish sites in August 2006. Measurements on capitulum bulk density and nutrient concentrations were executed as described above.

To measure the change in cover of the species in the mixtures, digital pictures were made at the start and at the end of the experiment. In these pictures we measured the total surface cover per species in each pot with Image $\mathbf{J}$ (Abramoff et al. 2004). The biomass production per unit area $\left(\mathrm{g} \mathrm{m}^{-2}\right)$ was calculated as follows:

height increment $(\mathrm{m})$

$\times$ final bulk density total sample $\left(\mathrm{g} \mathrm{m}^{-3}\right)$

$\times\left(\%\right.$ cover $_{\text {end }} / \%$ cover $\left._{\text {start }}\right)$.

\section{Data analysis}

Data were tested for normality and equality of variance. When necessary, data were square-root transformed to achieve homogeneous variances. Block effect was tested as random factor. When no block effect was detected, which was usually the case, block was omitted from the analysis to gain extra $d f$. All analyses were conducted using the SPSS statistical package for Windows (12.0).

One container with a monoculture of $S$. balticum under temperature 4 was heavily affected by a fungal infection, probably Lyophyllum palustre. After 4 months, $90 \%$ of the plant material had died. This container was further omitted from the analyses.

Height increment in monocultures was tested per species with one-way ANOVA with temperature as independent factor. Height increment, biomass production, cover change, bulk density, water content and nutrient concentrations were tested per species. Two-way ANOVAs were performed with temperature and species combination as independent factors. The effect of temperature, species and competition on the concentrations of $\mathrm{N}, \mathrm{P}$ and $\mathrm{K}$ was tested using a three-way ANOVA. Differences between the treatments were analysed using a Tukey post hoc test. To test how the environmental variables temperature, $\mathrm{N}$ concentration and water content influenced biomass production we performed a stepwise regression analysis per species. 


\section{Results}

Height increment

In the monocultures, the height increment increased with temperature in each species (Fig. 1, Table 2). For S. cuspidatum this effect was least distinct with the lowest height growth at temperature 2 and no difference in growth between temperatures 1,3 and 4 .

Only S. fuscum showed no difference in height increment between monoculture and mixture. All other species showed a growth reduction in mixtures (Table 2). There were no significant interactions between the effect of temperature and competition on height increment, except for $S$. balticum in combination with $S$. magellanicum (Table 2). Temperature increased height increment of S. balticum in monoculture, while there was no effect of temperature in mixture with S. magellanicum (Figs. 1b, 2 b). When we compared height increment between the two species in each mixture, the "wet" species S. balticum and S. cuspidatum had higher values than the "dry" species S. fuscum and S. magellanicum at temperature treatments 1 and 2 (Fig. 2). When temperature increased, the differences in height increment between the two species disappeared.

\section{Cover}

The hollow species $S$. balticum and $S$. cuspidatum increased in area in 53 out of 60 containers when growing in the mixtures. In the other seven containers (three with $S$. magellanicum $+S$. balticum, two with S. fuscum + $S$. balticum, two with $S$. magellanicum $+S$. cuspidatum), cover changed less than $5 \%$. For S. balticum there were significant effects of temperature $(F=3.67, P=0.023)$ and neighbouring species $(F=4.95, P=0.033)$ on expansion (Fig. 3a, b). Maximum change in cover was for
S. balticum in combination with $S$. fuscum with temperature 2 and 3 . There was no effect of temperature on expansion of $S$. cuspidatum (Fig. 3c, $F=0.88, P=$ $0.470)$.

\section{Biomass production}

The response of biomass production to the temperature treatments was similar to the response of height increment (Table 2). In all species biomass production increased with increased temperature. S. fuscum showed the strongest response; this species increased its biomass production 13-fold from the lowest to the highest temperature treatment in monocultures (Fig. 4a). Only for $S$. balticum in combination with $S$. magellanicum was there a significant interaction between temperature and species combination in biomass production (Table 2). Temperature increased biomass production of $S$. balticum in monoculture and in mixture with $S$. fuscum, while there was no effect of temperature in mixture with S. magellanicum.

When differences in biomass production between monocultures and mixtures are compared per temperature treatment, it shows that $S$. fuscum suffered from competition with $S$. balticum at temperature 3 because production was lower in mixture than in monoculture, but it no longer suffered at temperature 4 (Fig. 4a). At temperature 4 S. balticum does suffer from competition with $S$. fuscum, but not at lower temperatures. In the mixtures of $S$. $m a$ gellanicum and S. balticum, S. magellanicum suffers from competition at temperature 1 and 2, whereas $S$. balticum suffers from competition at temperature 3 and 4 (Fig. 4b). Biomass production of $S$. cuspidatum did not show any effect of competition with S. magellanicum, while biomass production of $S$. magellanicum did suffer from competition at temperatures 1, 2 and 3 (Fig. 4c).
Fig. 1 Height increment of species in monocultures $(\mathrm{cm})$. Data are mean values $\pm \mathrm{SE}$, $n=5$ except for Sphagnum balticum at T4, $n=4$. Different letters indicate significant differences $(P<0.05)$ between temperature treatments within each species. For temperature treatments, see Table 1

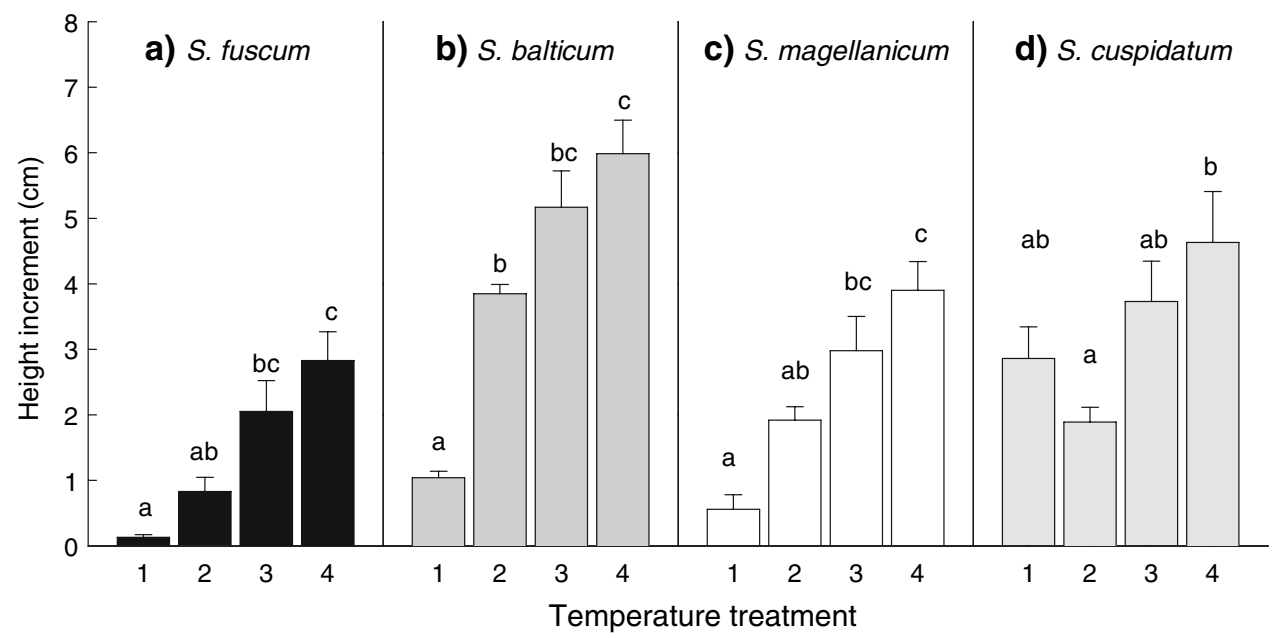


Table $2 F$-values and $P$-values and direction of main effects influencing height increment and biomass production per species ${ }^{\mathrm{a}}$, corrected for cover, using a two-way ANOVA

\begin{tabular}{|c|c|c|c|c|c|c|c|c|}
\hline & \multicolumn{3}{|c|}{ Temperature } & \multicolumn{3}{|c|}{ Combination } & \multicolumn{2}{|c|}{$\mathrm{T} \times$ combination } \\
\hline & $F$ & $P$ & Effect & $F$ & $P$ & Effect & $F$ & $P$ \\
\hline \multicolumn{9}{|l|}{ Height increment } \\
\hline Sphagnum fuscum (+Sphagnum balticum) & 49.31 & $<0.001$ & + & 1.17 & 0.288 & + & 0.92 & 0.445 \\
\hline S. balticum $(+S$. fuscum $)$ & 51.19 & $<0.001$ & + & 9.13 & 0.005 & - & 0.61 & 0.616 \\
\hline S. balticum (+Sphagnum magellanicum) & 19.58 & $<0.001$ & + & 10.32 & 0.003 & - & 3.24 & 0.035 \\
\hline S. magellanicum $(+S$. balticum $)$ & 28.71 & $<0.001$ & + & 8.87 & 0.006 & - & 1.88 & 0.154 \\
\hline S. magellanicum (+Sphagnum cuspidatum) & 18.53 & $<0.001$ & + & 4.86 & 0.035 & - & 1.14 & 0.350 \\
\hline S. cuspidatum $(+$ S. magellanicum $)$ & 10.80 & $<0.001$ & + & 18.83 & $<0.001$ & - & 0.86 & 0.470 \\
\hline \multicolumn{9}{|l|}{ Biomass production } \\
\hline S. fuscum $(+S$. balticum $)$ & 20.99 & $<0.001$ & + & 18.57 & $<0.001$ & - & 2.31 & 0.095 \\
\hline S. balticum $(+S$. fuscum $)$ & 19.41 & $<0.001$ & + & 5.48 & 0.026 & - & 2.04 & 0.128 \\
\hline S. balticum $(+S$. magellanicum $)$ & 9.68 & $<0.001$ & + & 12.38 & 0.001 & - & 3.47 & 0.028 \\
\hline S. magellanicum $(+S$. balticum $)$ & 17.50 & $<0.001$ & + & 44.99 & $<0.001$ & - & 1.67 & 0.193 \\
\hline S. magellanicum $(+S$. cuspidatum $)$ & 11.75 & $<0.001$ & + & 23.36 & $<0.001$ & - & 2.00 & 0.133 \\
\hline S. cuspidatum $(+$ S. magellanicum $)$ & 5.15 & 0.005 & + & 2.20 & 0.148 & - & 0.18 & 0.913 \\
\hline
\end{tabular}

${ }^{\text {a }}$ Number of observations $n=40$, except for S. balticum $n=39$

In the stepwise regression for biomass production of $S$. balticum, water content was selected as the most explanatory variable $\left(R^{2}=0.36, P<0.001\right)$. For biomass production of $S$. fuscum $\left(R^{2}=0.52, P<0.001\right)$, S. magellanicum $\left(R^{2}=0.36, P<0.001\right)$ and $S$. cuspidatum $\left(R^{2}=0.12, P=0.031\right)$, temperature was selected as the most explanatory variable.

\section{Bulk density}

Bulk densities were lower at higher temperatures for all species, except for bulk density of the capitula and stems of S. cuspidatum (Table 3). Compared to field values, capitulum bulk density of $S$. fuscum and S. balticum decreased with temperature, while capitulum bulk density of $S$. $m a$ gellanicum and $S$. cuspidatum seemed to increase at low temperatures.

Bulk densities of both capitula and stems were lower in mixtures than in monocultures of $S$. fuscum and S. balticum. Similarly, in S. cuspidatum the bulk density of the capitula was lower in mixtures than in monocultures. There were no significant interactions between temperature and species combination.

Nutrient concentrations

The concentrations of all nutrients $(\mathrm{N}, \mathrm{P}$ and $\mathrm{K})$ differed between species and rose with increasing temperature.
$\mathrm{N}$ concentration was also affected by the interactions of temperature by species $(F=2.66, P=0.007)$ and species by combination $(F=3.73, \quad P=0.006)$. At temperatures 1 and 2, $\mathrm{N}$ concentrations were lower for S. fuscum and S. balticum than for S. magellanicum and $S$. cuspidatum, as was also the case in field values. At temperature 3, only the $\mathrm{N}$ concentration of S. balticum was lower than that of $S$. magellanicum. At temperature 4, $\mathrm{N}$ concentrations of $S$. balticum were lower than those of $S$. magellanicum and S. fuscum (Table 4). Compared to field values, all species showed an increased $\mathrm{N}$ concentration with temperature.

$\mathrm{P}$ and $\mathrm{K}$ concentrations were affected by temperature (P concentration, $F=9.32, P<0.001 ; \mathrm{K}$ concentration, $F=82.77, P<0.001)$ and species (P concentration, $F=$ $3.05, P=0.031$; K concentration, $F=3.86, P=0.011$ ). $\mathrm{P}$ and $\mathrm{K}$ concentrations were higher at high temperature for all species (Table 4). $P$-values decreased, compared to field values, while $\mathrm{K}$ concentration increased compared to field values.

\section{Evaporation and water content}

Water content decreased with temperature treatment (Table 5). Water content was lowest in S. balticum in mixture with $S$. fuscum. Evaporation increased with temperature and therefore with VPD for all species (Table 5). Evaporation in S. fuscum in both monoculture and mixture was lower than in other species. 

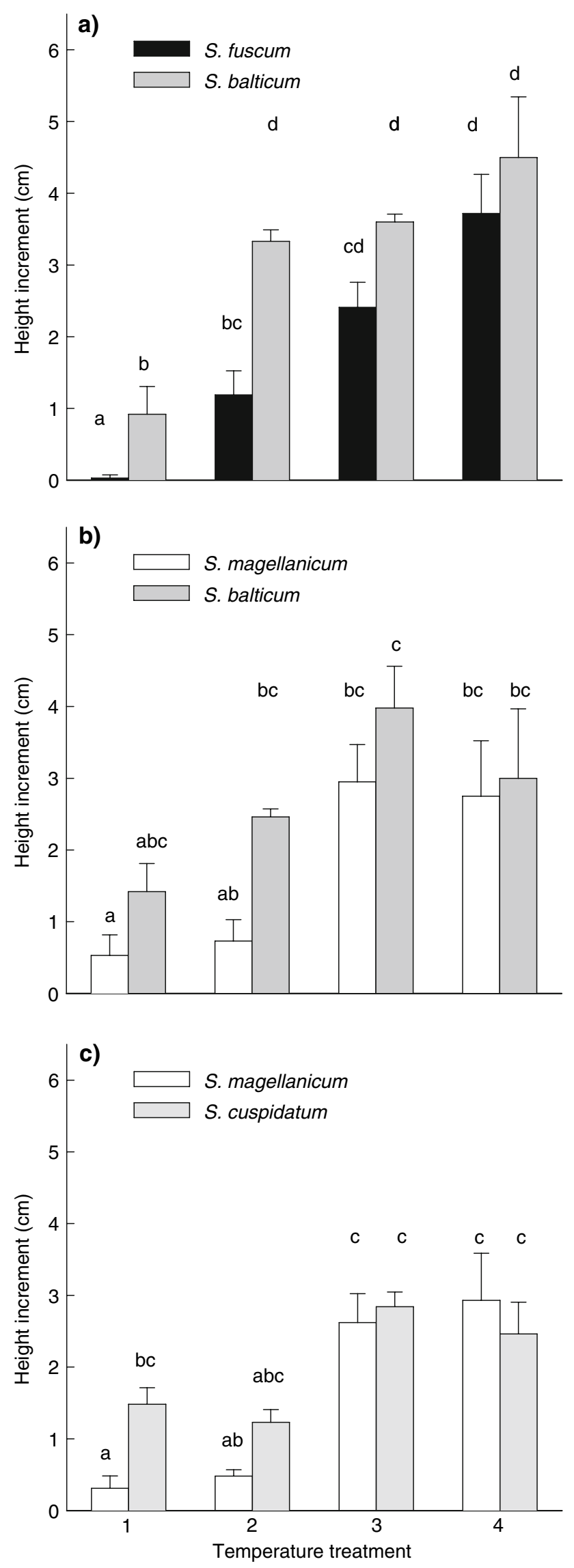

Fig. 2 Height increment of the individual species at each temperature treatment (see Table 1) within the three mixtures of species: a Sphagnum fuscum $+S$. balticum, b Sphagnum magellanicum + $S$. balticum and c $S$. magellanicum + Sphagnum cuspidatum. Data are mean values $\pm \mathrm{SE}, n=5$. Different letters indicate significant differences between treatments $(P<0.05)$

\section{Discussion}

Effect of temperature on growth

As expected, all species in monoculture increased height increment with temperature (Fig. 1). All species also showed a looser growth form with higher temperatures, which resulted in lower densities (Table 3). Despite the lower bulk density at higher temperatures, biomass production still increased with temperature for all species (Table 2, Fig. 4). The response of height increment to temperature was about a factor 2 larger than the response of biomass production. Growth of Sphagnum was probably increased by a higher rate of photosynthesis and a higher $\mathrm{N}$ availability. Photosynthesis in Sphagnum has been shown to increase with temperature up to an optimum around 20$25^{\circ} \mathrm{C}$ (Skre and Oechel 1981; Harley et al. 1989). When temperature increased, the nutrient concentrations in Sphagnum were higher (Table 4). Moreover, N and K concentration increased compared to field values (Table 4). As biomass production also increased, $\mathrm{N}$ and $\mathrm{K}$ uptake must have increased considerably with increasing temperature. No nutrients were added with the rainwater solution, so the higher availability of nutrients must have come from Sphagnum itself and the peat below. Probably the lower Sphagnum parts in the containers decomposed faster when the temperature was higher, making more $\mathrm{N}$ and $\mathrm{K}$ available for growth. This temperature-induced stimulation of nutrient mineralization is probably larger than it would be in field conditions as the peat soil in the containers is surrounded by warm air on every side, resulting in relatively high soil temperatures in our experiment. However, it can be expected that increased temperature as a result of climate change will also enhance decomposition rates in field situations (Hobbie 1996), thereby increasing nutrient availability for both Sphagnum and vascular plants. The lower N concentrations of $S$. fuscum and $S$. balticum compared with $S$. magellanicum and $S$. cuspidatum at temperatures 1 and 2 are probably caused by the different sites of origin. In the northern site, the $\mathrm{N}$ deposition is much lower (approximately $0.2 \mathrm{~g} \mathrm{~N} \mathrm{~m}^{-2}$ year $^{-1}$ ) than in the southern site (approximately $0.7 \mathrm{~g} \mathrm{~N} \mathrm{~m}^{-2}$ year $^{-1}$ ) where $S$. magellanicum and $S$. cuspidatum were collected.

In this experiment we provided near optimal growing conditions for Sphagnum with high water level and high humidity, which explains why the Sphagnum plants could grow with a lower bulk density and still keep their capitula 
Fig. 3 Cover change for hollow species: a $S$. balticum in combination with $S$. fuscum, b $S$. balticum in combination with $S$. magellanicum and $\mathbf{c} S$. cuspidatum in combination with $S$. magellanicum. Data are mean values $\pm \mathrm{SE}, n=5$. There were no significant differences between treatments $(P<0.05)$. For temperature treatments, see Table 1

moist. However, Sphagnum water content still decreased with an increase in temperature. In field conditions it would probably not have been possible for the Sphagnum plants to change their density so much since it would have led to problems in maintaining the water content of the capitula. The effect of temperature on height increment might therefore also have been less. In a few field studies, no positive or even negative effects of temperature on production were found. However, in these experiments there were other factors besides temperature that could have had a negative effect on biomass production, like drought stress (Hobbie et al. 1999; Weltzin et al. 2001; Gunnarsson et al. 2004) and higher vascular plant cover, which could have resulted in etiolation of the Sphagnum plants and reduced biomass production because of increased shading (Gunnarsson et al. 2004).

In other studies also positive effects of temperature on height growth and production were found for different species, in both greenhouse (Robroek et al. 2007b) and field experiments (Moore 1989; Gerdol 1995; Sonesson et al. 2002; Dorrepaal et al. 2003). In accordance with our hypothesis, Asada et al. (2003) suggested that Sphagnum species respond positively to increased temperature and that hollow and lawn species are more sensitive to temperature than hummock species. This, however, does not correspond with the low response of $S$. cuspidatum to temperature in our experiment. Dorrepaal et al. (2003) also found a decrease in bulk density with increased temperature. Since the response of height increment and bulk density to temperature were in opposite directions, the dry matter production of $S$. fuscum did not show a significant increase with temperature. Our relatively high height increment and low density of $S$. fuscum compared to the values of Dorrepaal et al. (2003) can probably be explained by the much higher water levels in our experiment. Dorrepaal et al. (2003) used water levels of -20 to $-40 \mathrm{~cm}$ below moss surface during their measurements. However, the Sphagnum densities we measured (Table 3) agreed quite well with densities from other studies (Lindholm and Vasander 1990; Moore et al. 1998; Asada et al. 2003).

From our results, we conclude that the height increment and biomass production of all Sphagnum species in bogs can increase with an increase in temperature. However, the literature shows us that, particularly under field conditions, this potential response may not be realized in instances of

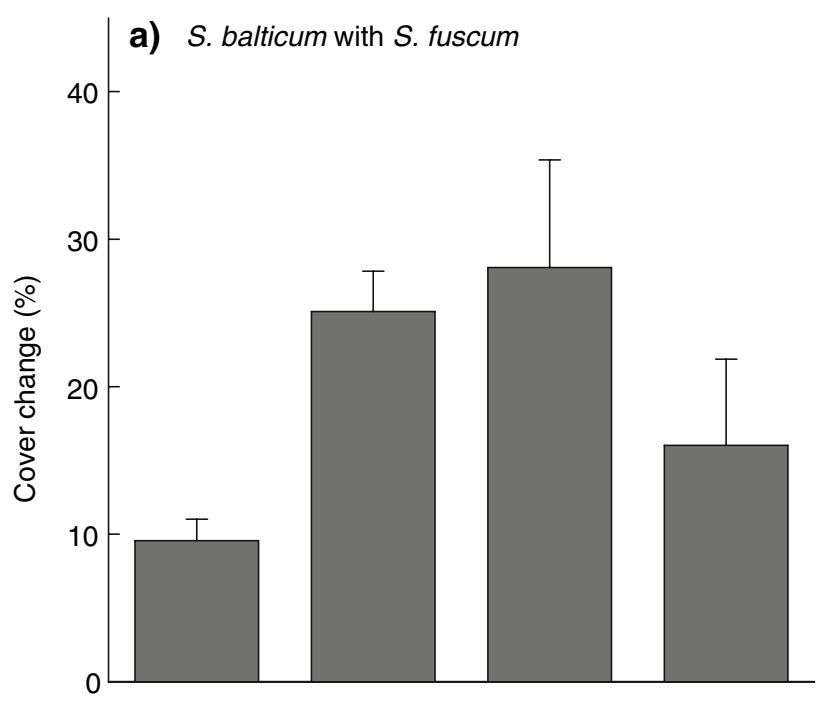

b) S. balticum with $S$. magellanicum

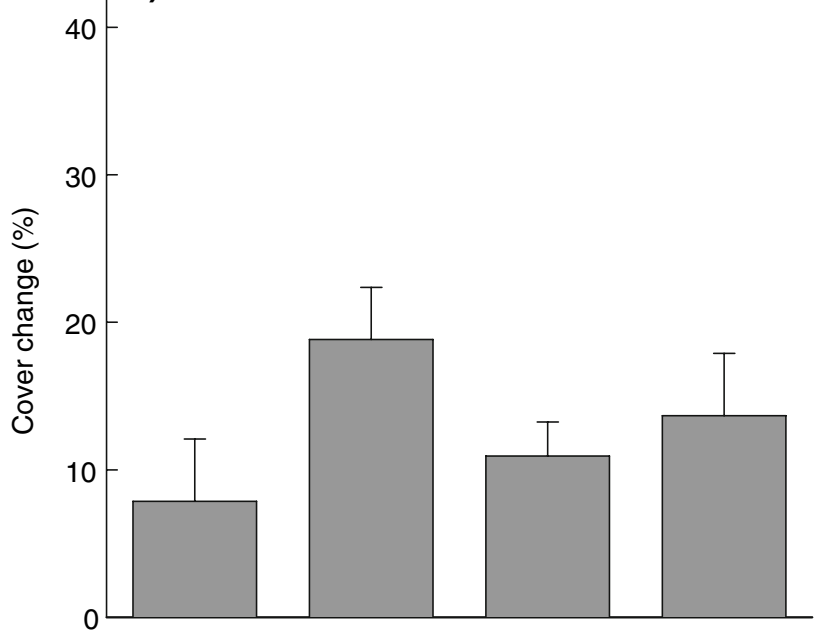

c) S. cuspidatum with S. magellanicum

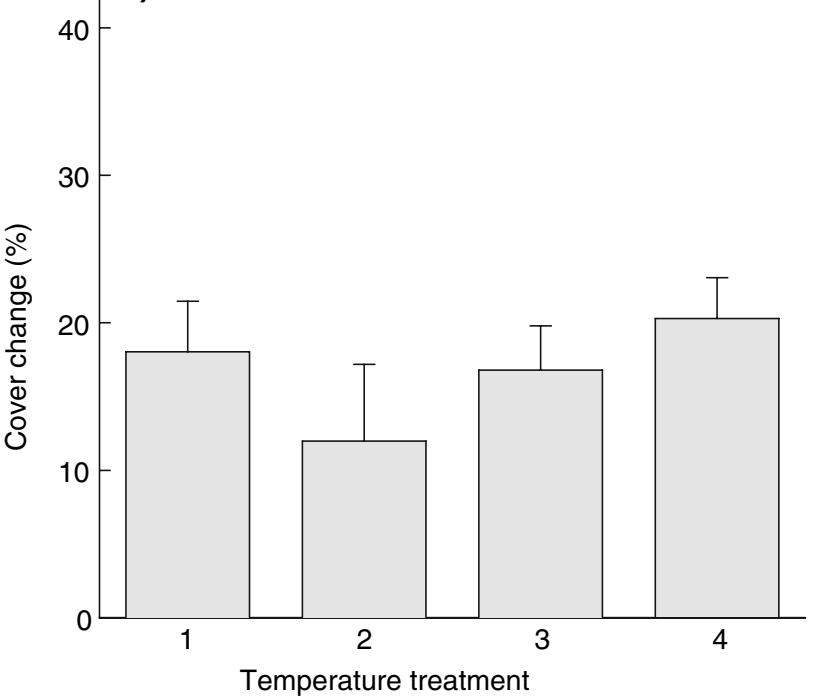


Fig. 4 Biomass production corrected for change in cover for species in monocultures (mono) and in mixtures (mix) for each temperature treatment (see Table 1) and species combination: a $S$. fuscum (fus) + S. balticum (bal),

b $S$. magellanicum (mag) + S. balticum and c $S$. magellanicum $+S$. cuspidatum (cus). Data are mean values $\pm \mathrm{SE}, n=4-5$. Different letters indicate significant differences between treatments $(P<0.05)$ a) S. fuscum + S. balticum
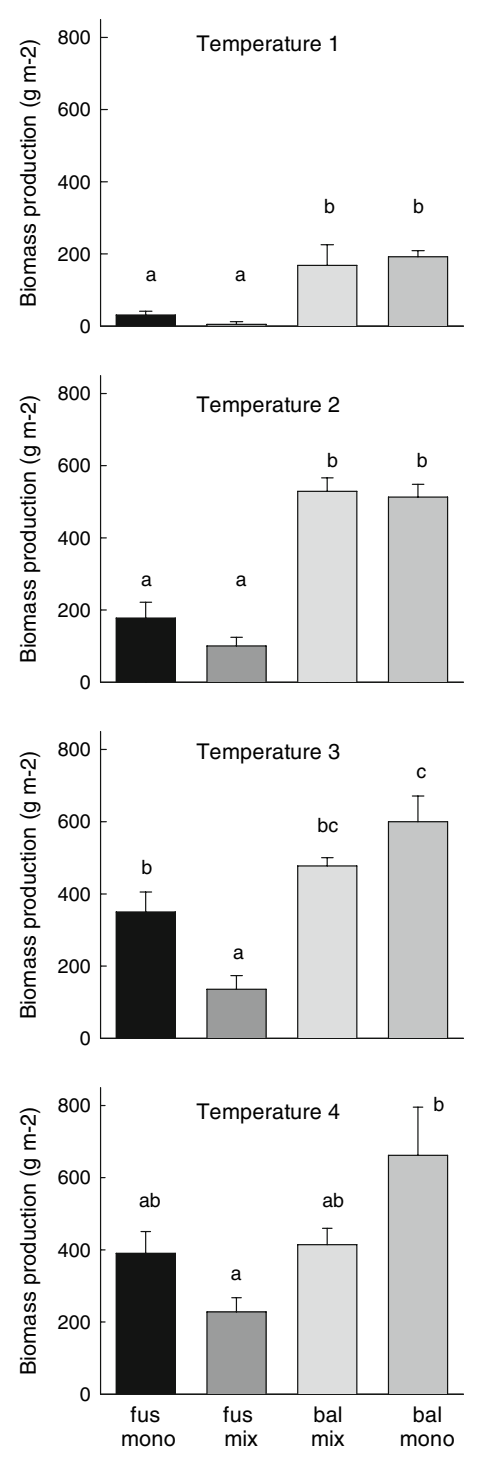

b) S. magellanicum $+S$. balticum
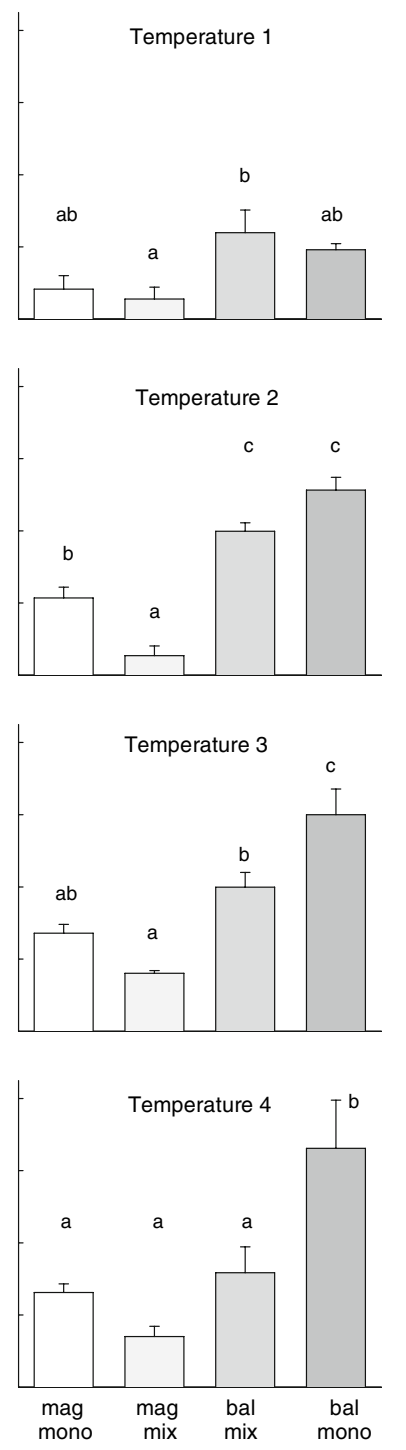

C) S. magellanicum + S. cuspidatum
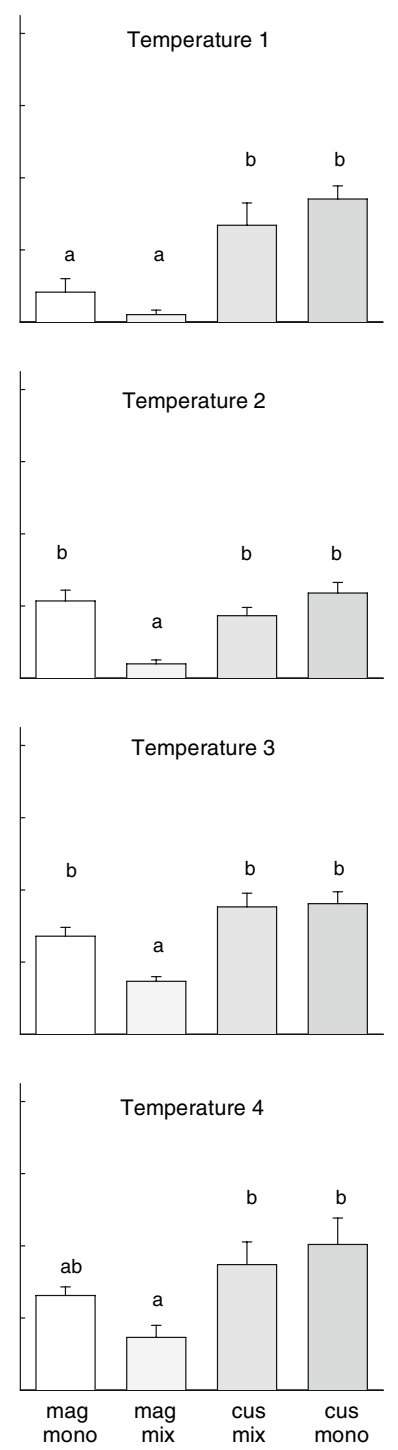

competition from vascular plants, drought stress or extreme temperature increases.

\section{Effect of temperature on competition}

We hypothesized that increased temperature will have a positive effect on competitive abilities of $S$. fuscum and S. magellanicum. This hypothesis was confirmed in the competition with $S$. balticum, since the height increment and biomass production of $S$. balticum at the highest temperature treatment were no longer larger than those of S. fuscum and S. magellanicum (Figs. 2, 4). However, $S$. balticum still increased its cover at the expense of S. fuscum and S. magellanicum in all mixtures (Fig. 3a, b). This could be expected as the water level we used was relatively high and in the range of the natural habitat of these species. These results correspond to the findings from a field experiment of Rydin (1986), who found an expansion of $S$. balticum at the expense of $S$. fuscum at a water level of $-1 \mathrm{~cm}$. At water levels of -5 and $-10 \mathrm{~cm}$, he found a small expansion of $S$. balticum, but at a water level of $-15 \mathrm{~cm} S$. fuscum showed large expansion.

In agreement with the hypothesis, the difference in height increment and biomass production between $S$. $f u$ scum and S. balticum disappeared as temperature increased (Figs. 2a, 4a). S. fuscum kept increasing height increment with temperature, but $S$. balticum already reached maximum height growth at temperature 2 , which is comparable to the summer temperature in the site of origin of these species. Also, the expansion in cover became lower for S. balticum at temperature 4 (Fig. 3a). As a result, the difference in biomass production between S. fuscum and S. balticum slowly decreased with an increase in 
Table 3 Bulk density of capitula section, stem section and total sample. Data are mean values \pm SE, pooled within temperature treatment (see Table 1) and within competition treatment. Different letters indicate significant differences between treatments within a species $(P<0.05)$. There were no significant interactions between temperature and competition treatments. fus S. fuscum, bal S. balticum, mag S. magellanicum, cus S. cuspidatum

\begin{tabular}{|c|c|c|c|c|c|c|c|c|c|}
\hline & \multirow[t]{2}{*}{ Field value } & \multicolumn{4}{|c|}{ Temperature } & \multicolumn{4}{|c|}{ Combination } \\
\hline & & $\mathrm{T} 1$ & $\mathrm{~T} 2$ & $\mathrm{~T} 3$ & $\mathrm{~T} 4$ & Mono & fus-bal & mag-bal & mag-cus \\
\hline \multicolumn{10}{|c|}{ Bulk density capitula $\left(\mathrm{mg} \mathrm{cm}^{-3}\right)$} \\
\hline S. fuscum & $38 \pm 2$ & $35 \pm 2^{b}$ & $37 \pm 2^{b}$ & $21 \pm 1^{\mathrm{a}}$ & $17 \pm 1^{\mathrm{a}}$ & $30 \pm 2^{b}$ & $25 \pm 2^{\mathrm{a}}$ & - & - \\
\hline S. balticum & $32 \pm 1$ & $26 \pm 1^{b}$ & $16 \pm 1^{\mathrm{a}}$ & $14 \pm 1^{\mathrm{a}}$ & $14 \pm 1^{\mathrm{a}}$ & $20 \pm 1^{\mathrm{b}}$ & $18 \pm 2^{b}$ & $15 \pm 1^{\mathrm{a}}$ & - \\
\hline S. magellanicum & $19 \pm 1$ & $21 \pm 1^{\mathrm{b}}$ & $18 \pm 1^{\mathrm{b}}$ & $13 \pm 1^{\mathrm{a}}$ & $13 \pm 1^{\mathrm{a}}$ & $17 \pm 1$ & - & $15 \pm 1$ & $17 \pm 1$ \\
\hline S. cuspidatum & $19 \pm 1$ & $23 \pm 1$ & $22 \pm 2$ & $19 \pm 1$ & $19 \pm 1$ & $23 \pm 1^{\mathrm{b}}$ & - & - & $19 \pm 1^{\mathrm{a}}$ \\
\hline \multicolumn{10}{|c|}{ Bulk density stems $\left(\mathrm{mg} \mathrm{cm}^{-3}\right)$} \\
\hline S. fuscum & $18 \pm 1^{\mathrm{b}}$ & $16 \pm 1^{b}$ & $15 \pm 2^{\mathrm{ab}}$ & $11 \pm 2^{\mathrm{a}}$ & $17 \pm 1^{b}$ & $14 \pm 1^{\mathrm{a}}$ & - & - & \\
\hline S. balticum & $15 \pm 1^{\mathrm{b}}$ & $11 \pm 1^{\mathrm{a}}$ & $8 \pm 1^{\mathrm{a}}$ & $9 \pm 1^{\mathrm{a}}$ & $13 \pm 1^{b}$ & $9 \pm 1^{\mathrm{a}}$ & $11 \pm 1^{\mathrm{ab}}$ & - & \\
\hline S. magellanicum & $11 \pm 1^{\mathrm{c}}$ & $9 \pm 0^{\mathrm{bc}}$ & $8 \pm 1^{\mathrm{ab}}$ & $7 \pm 0^{\mathrm{a}}$ & $9 \pm 1$ & - & $9 \pm 1$ & $8 \pm 0$ & \\
\hline S. cuspidatum & $10 \pm 1$ & $10 \pm 1$ & $7 \pm 1$ & $7 \pm 1$ & $8 \pm 1$ & - & - & $9 \pm 1$ & \\
\hline \multicolumn{10}{|c|}{ Bulk density total sample $\left(\mathrm{mg} \mathrm{cm}^{-3}\right)$} \\
\hline S. fuscum & $22 \pm 1^{\mathrm{c}}$ & $21 \pm 1^{\mathrm{bc}}$ & $17 \pm 1^{\mathrm{ab}}$ & $13 \pm 1^{\mathrm{a}}$ & $20 \pm 1^{b}$ & $16 \pm 1^{\mathrm{a}}$ & - & - & \\
\hline S. balticum & $17 \pm 1^{\mathrm{b}}$ & $12 \pm 1^{\mathrm{a}}$ & $10 \pm 1^{\mathrm{a}}$ & $10 \pm 1^{\mathrm{a}}$ & $14 \pm 1^{\mathrm{b}}$ & $11 \pm 1^{\mathrm{a}}$ & $12 \pm 1^{\mathrm{ab}}$ & - & \\
\hline S. magellanicum & $13 \pm 1^{\mathrm{c}}$ & $11 \pm 0^{\mathrm{b}}$ & $9 \pm 1^{\mathrm{a}}$ & $8 \pm 0^{\mathrm{a}}$ & $11 \pm 1$ & - & $10 \pm 1$ & $10 \pm 0$ & \\
\hline S. cuspidatum & $12 \pm 1^{\mathrm{c}}$ & $12 \pm 0^{\mathrm{bc}}$ & $10 \pm 1^{\mathrm{ab}}$ & $9 \pm 0^{\mathrm{a}}$ & $11 \pm 1$ & - & - & $11 \pm 0$ & \\
\hline
\end{tabular}

Values for material from the sites of origin (Field values, $n=5$ ) are given for comparison. Number of observations for each species for each temperature treatment: $S$. fuscum and $S$. cuspidatum, $n=10 ; S$. balticum, $n=14-15 ; S$. magellanicum, $n=15$. Number of observations for each species for each combination, $n=19-20$

temperature until there was no significant difference at the highest temperature. Apparently, the hummock species $S$. fuscum is better able to profit from a high increase in temperature than S. balticum, even at relatively high water levels. This is confirmed by the stepwise regression analysis which shows that biomass production of S. fuscum is correlated most to temperature, and biomass production of $S$. balticum to water content. As could be expected, $S$. $f u$ scum as a hummock species has a higher water content than S. balticum, also at higher temperatures (Table 5), and therefore can profit more from increased temperature, because water does not become limiting for growth. $S$. fuscum also seems to be the better competitor for nutrients. The $\mathrm{N}$ and $\mathrm{P}$ concentrations in $\mathrm{S}$. fuscum tended to be higher in the mixtures than in the monocultures, whereas in $S$. balticum the opposite was the case (Table 4). Indeed, $S$. fuscum is known for its high $\mathrm{N}$ uptake rate (Jauhiainen et al. 1998). Our results show that S. balticum loses competitive strength with increasing temperature. With a slight increase in temperature in northern bogs, $S$. balticum may remain the stronger competitor at high water levels, but at higher temperature increases, S. fuscum will gain a competitive advantage over S. balticum, also because increased temperature may lead to lower water tables in bogs. Recent climate change simulation models predict an increase of $2.5^{\circ} \mathrm{C}$ in summer temperature in northern Europe, with increasing precipitation in northern Scandinavia
(Christensen et al. 2007). This limited rise in temperature, almost similar to the increase from temperature 2 to 3 , would not affect competition between S. balticum and S. fuscum very strongly. However, the effect of a predicted increase in winter temperature of $5.0^{\circ} \mathrm{C}$ (Christensen et al. 2007) could shift the competitive balance between $S$. balticum and S. fuscum further, because increased snow cover and spring temperature have been shown to increase S. fuscum production (Dorrepaal et al. 2003).

For S. magellanicum and S. cuspidatum, temperature 3 is comparable to the summer temperature in their site of origin. There was no effect of a temperature increase from temperature 3 to 4 on biomass production and relative performance of the species. This implies that with the predicted increase in temperature of $2.5^{\circ} \mathrm{C}$ (Christensen et al. 2007), the competitive balance between S. magellanicum and $S$. cuspidatum will remain unchanged.

The mixtures of $S$. balticum and $S$. magellanicum show the largest difference in height increment and biomass production at temperature 2 , which is comparable to the summer temperature in the site of origin of S. balticum. Also the expansion in cover of $S$. balticum was highest at this temperature. When temperature increases, the difference in height growth and biomass production became smaller and then disappeared in mixtures, whereas in monocultures the difference in biomass production between species remained. This implies that $S$. balticum as 


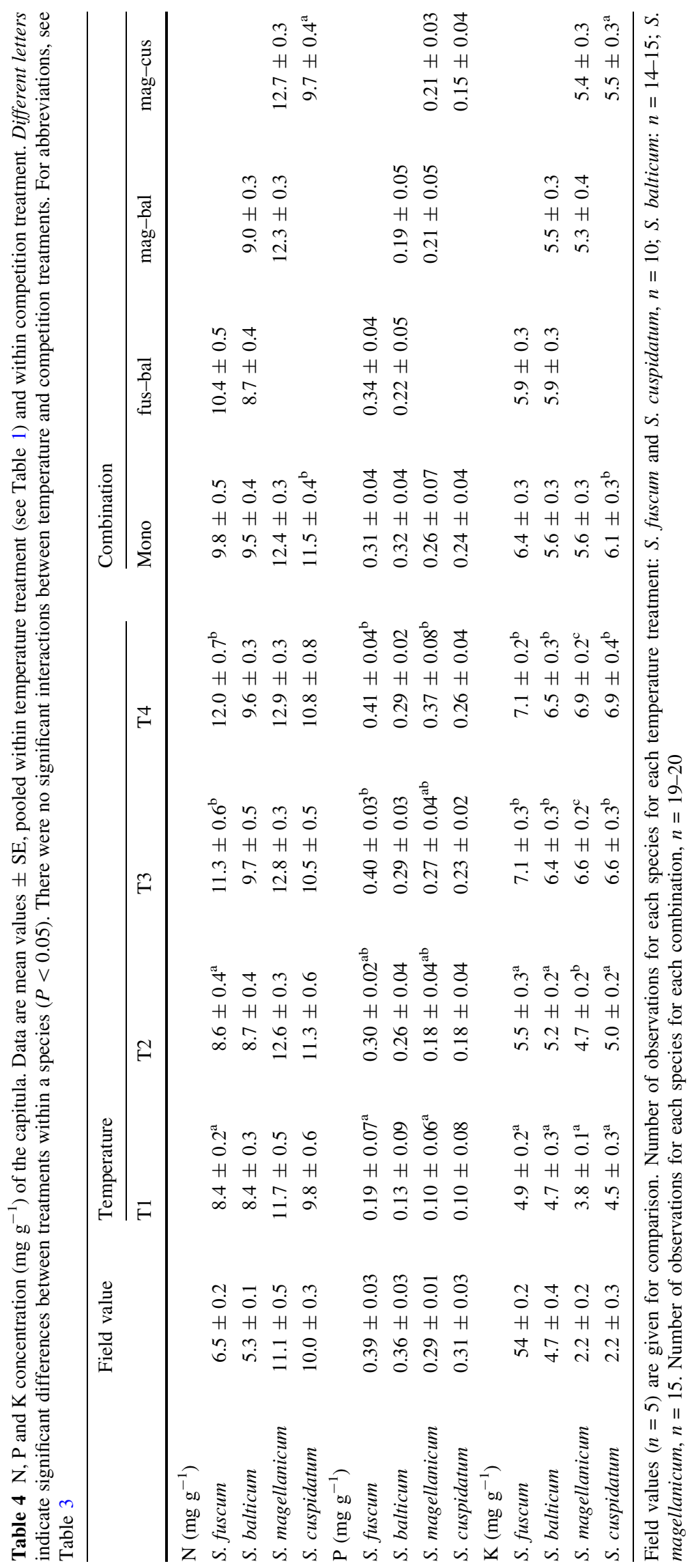


Table 5 Water content (\% volume) at $5 \mathrm{~cm}$ depth and evaporation $\left(\mathrm{mm} \mathrm{day}^{-1}\right)$ per temperature treatment ${ }^{\mathrm{a}}$ (see

Table 1) and per species combination $^{\mathrm{b}}$. Data are mean values \pm SE. Different letters indicate significant differences between treatments $(P<0.05)$. There were no significant interactions between temperature and competition treatments

Number of observations for each temperature treatment: for water content, $n=50$; for evaporation, $n=35$. Number of observations for each competition treatment: for water content and for evaporation, $n=20$
Water content

Evaporation

\begin{tabular}{llll}
\hline Temperature & & & \\
1 & $88 \pm 2^{\mathrm{c}}$ & 1 & $1.2 \pm 0.02^{\mathrm{a}}$ \\
2 & $79 \pm 3^{\mathrm{b}}$ & 2 & $1.5 \pm 0.03^{\mathrm{b}}$ \\
3 & $60 \pm 3^{\mathrm{a}}$ & 3 & $1.7 \pm 0.04^{\mathrm{c}}$ \\
4 & $60 \pm 3^{\mathrm{a}}$ & 4 & $2.0 \pm 0.05^{\mathrm{d}}$ \\
Monocultures & & & \\
S. fuscum & $83 \pm 5^{\mathrm{c}}$ & S. fuscum & $1.3 \pm 0.05^{\mathrm{a}}$ \\
S. balticum & $66 \pm 6^{\mathrm{b}}$ & S. balticum & $1.7 \pm 0.08^{\mathrm{bc}}$ \\
S. magellanicum & $74 \pm 4^{\mathrm{bc}}$ & S. magellanicum & $1.8 \pm 0.08^{\mathrm{c}}$ \\
S. cuspidatum & $78 \pm 4^{\mathrm{bc}}$ & S. cuspidatum & $1.8 \pm 0.08^{\mathrm{c}}$ \\
Mixtures & & & \\
S. fuscum & $74 \pm 5^{\mathrm{bc}}$ & S. fuscum + S. balticum & $1.5 \pm 0.07^{\mathrm{a}}$ \\
S. balticum & $49 \pm 5^{\mathrm{a}}$ & & \\
S. magellanicum & $69 \pm 5^{\mathrm{b}}$ & S. magellanicum + S. balticum & $1.6 \pm 0.07^{\mathrm{b}}$ \\
S. balticum & $68 \pm 5^{\mathrm{b}}$ & & \\
S. magellanicum & $82 \pm 5^{\mathrm{c}}$ & S. magellanicum + S. cuspidatum & $1.7 \pm 0.08^{\mathrm{bc}}$ \\
S. cuspidatum & $73 \pm 5^{\mathrm{bc}}$ & & \\
\hline
\end{tabular}

a northern species can enhance its production with an increase in temperature as long as it grows in monocultures. If $S$. magellanicum expanded its distribution further to the north as a result of global warming, it would be a strong competitor for $S$. balticum, thereby reducing S. balticum production. Gunnarsson et al. (2004) also showed that $S$. balticum performs less well under competition with increased temperatures. They performed a competition experiment in a poor fen, close to the site of origin of the S. balticum material. They found that when Sphagnum papillosum was transplanted to an area with S. balticum, S. papillosum decreased in area by $30 \%$. However, when temperature was increased by $3.6^{\circ} \mathrm{C}$, $S$. papillosum increased by $42 \%$. This treatment is comparable to the increase from temperature 2 to temperature 3 in our experiment but with lower water tables, ranging from 5 to $17 \mathrm{~cm}$ under the moss surface.

Generally, we conclude from our experiment that an increase in temperature can favour hummock and lawn species compared to hollow species. This corresponds to the findings of Mauquoy et al. (2002), who showed from peat core analyses that in periods with lower temperature, due to decreased solar activity, there was a shift in representation from lawn and hummock species to hollow species in ombrotrophic mires in Denmark and the UK.

In conclusion, our findings suggest that production rates can increase and that Sphagnum species' abundances can shift in response to global warming, particularly at northern sites. There, hollow species such as $S$. balticum will lose competitive strength relative to hummock species such as $S$. fuscum and southern species such as $S$. magellanicum. What the consequences for the $\mathrm{C}$ balance of bog ecosystems will be depends not only on the production rates, but also on decomposition. In general, decomposition rates also increase with temperature and increased $\mathrm{N}$ availability (Hobbie 1996; Limpens and Berendse 2003) and hummock species decompose slower than hollow species (Rochefort et al. 1990; Johnson and Damman 1993; Limpens and Berendse 2003), but virtually nothing is known about the temperature sensitivity of decomposition of bog plant species.

Acknowledgments We thank Maurits Gleichman and Frans Möller for their practical assistance in the greenhouse and with separating and weighing all the samples, and we thank Jan van Walsem for the chemical analysis. We also thank Urban Gunnarsson and two anonymous reviewers for their constructive comments on this manuscript. This study was financed by the Netherlands Organization for Scientific Research (NWO-project 110015-01). The experiments presented in this paper comply with the current laws of the Netherlands.

Open Access This article is distributed under the terms of the Creative Commons Attribution Noncommercial License which permits any noncommercial use, distribution, and reproduction in any medium, provided the original author(s) and source are credited.

\section{References}

Abramoff MD, Magelhaes PJ, Ram SJ (2004) Image processing with imageJ. Biophotonics Int 11:36-42

Alexandersson H, Karlström C, Larsson-McCann S (1991) Temperature and precipitation in Sweden 1961-90. Reference normals. Swedish Meterological and Hydrological Institute (SMHI), Meterologi, Norrköping

Andrus RE (1986) Some aspects of Sphagnum ecology. Can J Bot 64:416-426 
Asada T, Warner BG, Banner A (2003) Growth of mosses in relation to climate factors in a hypermaritime coastal peatland in British Columbia, Canada. Bryologist 106:516-527

Belyea LR (1996) Separating the effects of litter quality and microenvironment on decomposition rates in a patterned peatland. Oikos 77:529-539

Christensen JH, et al. (2007) 2007: Regional climate projections. Cambridge University Press, Cambridge, New York

Clymo RS (1970) The growth of Sphagnum: methods of measurement. J Ecol 58:13-49

Clymo RS, Hayward PM (1982) The ecology of Sphagnum. In: Smith AJE (ed) Bryophyte ecology. Chapman \& Hall, London, pp 229289

Coulson JC, Butterfield J (1978) An investigation of the biotic factors determine the rates of plant decomposition on blanket bog. J Ecol 66:631-650

Daniels RE, Eddy A (1985) Handbook of European Sphagna. HMSO, London

Dorrepaal E, Aerts R, Cornelissen JHC, Callaghan TV, van Logtestijn RSP (2003) Summer warming and increased winter snow cover affect Sphagnum fuscum growth, structure and production in a sub-arctic bog. Glob Change Biol 10:93-104

Garrels RM, Christ CL (1965) Solutions, minerals and equilibria. Harper and Row, New York

Gerdol R (1995) The growth dynamics of Sphagnum based on field measurements in a temperate bog and on laboratory cultures. J Ecol 83:431-437

Gorham E (1991) Northern peatlands: role in the carbon cycle and probable responses to climatic warming. Ecol Appl 1:182-195

Grosvernier P, Matthey Y, Buttler A (1997) Growth potential of three Sphagnum species in relation to water table level and peat properties with implications for their restoration in cut-over bogs. J Appl Ecol 34:471-483

Gunnarsson U (2005) Global patterns of Sphagnum productivity. J Bryol 27:269-279

Gunnarsson U, Granberg G, Nilsson M (2004) Growth, production and interspecific competition in Sphagnum: effects of temperature, nitrogen and sulphur treatments on a boreal mire. New Phytol 163:349-359

Harley PC, Tenhunen JD, Murray KJ, Beyers J (1989) Irradiance and temperature effects on photosynthesis of tussock tundra Sphagnum mosses from the foothills of the Philip Smith Mountains, Alaska. Oecologia 79:251-259

Hobbie SE (1996) Temperature and plant species control over litter decomposition in Alaskan tundra. Ecol Monogr 66:503-522

Hobbie SE, Chapin FS III (1998) The response of tundra plant biomass, aboveground production, nitrogen and $\mathrm{CO}_{2}$ flux to experimental warming. Ecology 79:1526-1544

Hobbie SE, Shevtsova A, Chapin FS III (1999) Plant responses to species removal and experimental warming in Alaskan tussock tundra. Oikos 84:417-434

Jauhiainen J, Wallén B, Malmer N (1998) Potential $\mathrm{NH}_{4}{ }^{+}$and $\mathrm{NO}_{3}{ }^{-}$ uptake in seven Sphagnum species. New Phytol 138:287-293

Johnson LC, Damman WH (1993) Decay and its regulation in Sphagnum peatlands. Adv Bryol 5:249-296
Kivinen E, Pakarinen P (1980) Peatland areas and the proportion of virgin peatlands in different countries. In: Proceedings of the 6th International Peat Congress, Duluth, pp 52-54

Limpens J, Berendse F (2003) How litter quality affects mass loss and N loss from decomposing Sphagnum. Oikos 103:537-547

Limpens J, Tomassen HB, Berendse F (2003) Expansion of Sphagnum fallax in bogs: striking the balance between $\mathrm{N}$ and $\mathrm{P}$ availability. J Bryol 25:83-90

Lindholm T, Vasander H (1990) Production of eight species of Sphagnum at Suuriso mire, southern Finland. Ann Bot Fenn 27:145-157

Malmer N, Albinsson C, Svensson BM, Wallen B (2003) Interferences between Sphagnum and vascular plants: effects on plant community structure and peat formation. Oikos 100:469-482

Mauquoy D, van Geel B, Blaauw M, van der Plicht J (2002) Evidence from northwest European bogs shows 'Little Ice Age' climatic changes driven by variations in solar activity. Holocene 12:1-6

Mooney HA (1991) Biological response to climate change: an agenda for research. Ecol Appl 1:112-117

Moore TR (1989) Growth and net production of Spagnum at five fen sites, subartic eastern Canada. Can J Bot 67:1203-1207

Moore TR, Roulet NT, Waddington JM (1998) Uncertainty in predicting the effect of climatic change on the carbon cycling of Canadian peatlands. Clim Change 40:229-245

Robroek B, Limpens J, Breeuwer A, Crushell P, Schouten M (2007a) Interspecific competition between Sphagnum mosses at different water tables. Funct Ecol 21:805-812

Robroek BJM, Limpens J, Breeuwer A, Schouten MGC (2007b) Effects of water level and temperature on performance of four Sphagnum mosses. Plant Ecol 190:97-107

Rochefort L, Vitt DH, Bayley SE (1990) Growth, production and decomposition dynamics of Sphagnum under natural and experimentally acidified conditions. Ecology 71:1986-2000

Rydin H (1986) Competition and niche separation in Sphagnum. Can J Bot 64:1817-1824

Rydin H (1993) Interspecific competition between Sphagnum mosses on a raised bog. Oikos 66:413-423

Rydin H (1997) Competition among bryophytes. Adv Bryol 6:135168

Rydin H, McDonald AJS (1985) Tolerance of Sphagnum to water level. J Bryol 13:571-578

Sjörs H, Gunnarsson U (2002) Calcium and pH in north and central Swedish mire waters. J Ecol 90:650-657

Skre O, Oechel WC (1981) Moss functioning in different taiga ecosystems in interior Alaska I. Seasonal, phenotypic, and drought effects on photosynthesis and response patterns. Oecologia 48:50-59

Smith AJE (1978) The moss flora of Britain and Ireland. Cambridge University Press, Cambridge

Sonesson M, et al (2002) Growth of two peat-forming mosses in subarctic mires: species interactions and effects of simulated climate change. Oikos 99:151-160

Weltzin JF, Harth C, Bridgham SD, Pastor J, Vonderharr M (2001) Production and microtopography of bog bryophytes: response to warming and water-table manipulations. Oecologia 128:557-565 